\title{
Effect of Plant Density and intercropping Pattern on yield and Competitive Relationships of Maize and Cowpea
}

\author{
Mohammed A. Hassan ${ }^{1}$, Maged S. S. Ba-Muaafa ${ }^{1}$, Kamela A.R. Ibrahim ${ }^{2}$
}

\begin{abstract}
Two field experiments were carried out at Research Farm of Alkod Station (Delta of Abyan) in 2012/2013 and 2013/2014 seasons to study the effect of plant density and intercropping pattern as well as their interaction on yield and competitive relationships of maize and cowpea. Four plant densities were used $(56000,67000,83000$ and 111000 plants /hectare) and three intercropping patterns (1:1, 2:1 and 3:3) for maize and cowpea respectively, in addition to sole cropping treatment. The results could be summarized as follows:
\end{abstract}

- Increasing plant density significantly increased biological and grain yield of maize while harvest index was decreased. Intercropping patterns significantly reduced biological and grain yield of maize while harvest index was increased. Interaction between plant densities and intercropping patterns significantly affected biological and grain yield of maize as well as harvest index and the maximum grain yield was obtained under 2:1 intercropping pattern at 83000 plants/ hectare.

- Biological and seed yield of cowpea were significantly increased by increasing plant density while harvest index was decreased with significant value in the second season. Intercropping patterns significantly reduced biological and seed yield while harvest index was increased. The interaction between plant densities and intercropping patterns had significant effect on biological and seed yield of cowpea in both seasons as well as harvest index in the second season and the highest seed yield was obtained under $3: 3$ patterns at 111000 plants/ hectare. Land equivalent ratio( LER) and relative crowding coefficient $(K)$ values indicated that intercropping cowpea with maize gave yield advantage at all combinations of plant densities and intercropping patterns and the highest values of LER (1.51 and 160) in the first and second seasons respectively were obtained under $3: 3$ pattern at 111000 plants/ hectare.

- Aggressivity values and competitive ratio indicated that maize was the dominant intercrop while cowpea was the dominated intercrop.

Key words: intercropping patterns, maize, cowpea, plant density.

\section{INTRODUCTION}

The need for an intensive cropping culture in Yemen to raise the production per unit of land area has become a highly required demand, because the acreage reserved for a special crop is relatively limited. Intercropping cereals with legumes often increase the total yield due to better utilization of environmental resources. In this connection, Fisher (1977) indicated that intercropping maize with some legumes gave yield advantage over pure stand. Yield advantage was attributed to the increase in population of these mixtures. Remison (1978) also indicated that mean yields of maize and cowpea mixture out-yielded those of pure stand. High complementation values were recorded from intercropping.

Marfa et al. (1979) found yield advantage of 58\% when intercropped cowpea into maize between rows. Allen and Gboura (1983) indicated that the average LER of the maize-cowpea intercropping system was greater than unity and greater than maize-soybean intercropping pattern. Asafu Agyei et al. (1997) found that intercropping maize and cowpea using 3:3 system was more productive than 1:1 system. Shivay and Sing (2000)intercropped maize and cowpea at different plant densities and found that biological and grain yield of maize and cowpea were significantly decreased under intercropping as well as at low plant density.

Al-Shebani and Alazaki (2006) studied the effect of intercropping system (on the same ridge, 1:1, 2:2 and $3: 3$ ) and maize plant density (50000, 60000 and 70000 plants/hectare) on yield and yield components of maize and beans and found that biological and grain yield of maize and beans were significantly reduced by intercropping as well as when reducing plant density while harvest index was increased. Hassan et. al. (2008) intercropped cowpea on maize ridges (100\% maize and $100 \%$ cowpea). They found that intercropping system significantly reduced biological and seed yield of cowpea and biological and grain yield of maize. Land equivalent ratio, relative crowding coefficient and cereal units values indicated that intercropping system gave yield advantage. The values of aggressivity and competitive ratio indicated that maize was the dominant intercrop while cowpea was dominated intercrop.

Ahmed and Baswiad (2009) found that yields of maize and cowpea were significantly reduced under intercropping patterns. LER exceeded one under all intercropping patterns except 1:2 pattern and the greater LER was under 1:1 maize cowpea intercropping pattern.

\footnotetext{
${ }^{1}$ Nasser's Faculty of Agric. Sci. University of Aden

${ }^{2}$ Agric. Res. Station of Alkode Delta of Abyan

Received May 19, 2016, Accepted June 13, 2016
} 
Al-Shebani and Alazaki (2012) intercropped maize with beans under four patterns (on the same ridge, $1: 1$, $2: 2$ and $3: 3$ ) and at three maize population (50000, 60000 and 70000 plant/hectare) . They found that total LER and $\mathrm{K}$ values were greater than unity under all combinations of intercropping patterns and densities and maize was always the dominant component while the legume was the dominated component when aggressivity and competitive ratio were measured. Gabatshela et. al. (2012) intercropped maize and cowpea in alternative rows at space 30 and $40 \mathrm{~cm}$ between rows and found that biological and seed yield of cowpea was significantly reduced by intercropping system and this reduction was increased under low plant density of intercrops. The aim of this study to evaluate some intercropping patterns of maize and cowpea at different plant densities.

\section{MATERIALS AND METHODS}

Two experiments were carried out at Research Farm of Alkod Agricultural Station during 2012/2013 and $2013 / 2014$ seasons to study the effect of plant density and intercropping pattern on yield and competitive relationships of maize and cowpea. Before conducting the experiment, soil samples were taken from different places representing the experimental sites for analysis. The average of mechanical and chemical analysis of soil of the two growing seasons is presented in Table (1).

Sity Lagoos 7931 maize cultivar and cowpea Balady cultivar were used in this study. The experimental treatments were sixteen which were the combinations of four intercropping treatments and four plant densities as follows:

- Intercropping treatments (maize: cowpea)

$1-1: 1$

2- $2: 1$

3- 3:3

4- Sole cropping

- Plant densities (plants/hectare)
1 - 56000
$(30 \mathrm{~cm} \mathrm{X} 60 \mathrm{~cm})$
2- 67000
$(25 \mathrm{~cm} \times 60 \mathrm{~cm})$
3- 83000
$(20 \mathrm{~cm} \times 60 \mathrm{~cm})$
4- 111000
$(15 \mathrm{~cm}$ X $60 \mathrm{~cm})$

The experimental design was a split plot with four replicates. The intercropping patterns distributed randomly in the main plots and the plant densities in the sub-plots and the sub-plot contains 12 rows each of 3.0 $\mathrm{m}$ in length and $0.6 \mathrm{~m}$ in width. Maize and cowpea were planted at the same time on December 16 and 12, in the first and second seasons respectively. Phosphorous fertilizer was applied at the rate of $60 \mathrm{~kg}$ phosphor/hectare in the form of calcium super phosphate $\left(46 \% \mathrm{P}_{2} \mathrm{O}_{5}\right)$ during seedbed preparation, and nitrogen fertilizer was applied at rate of $120 \mathrm{~kg}$ $\mathrm{N} /$ hectare in form of urea $(46 \mathrm{~N} \%)$ in two equal doses before the second and fourth irrigations. Plants were thinned before the second irrigation leaving one plant/hill for both crops. The other agricultural practices were done according to the recommendations. The characters studied were as follows:

A - Maize characters

1- Biological yield/hectare.

2- Grain yield/hectare.

3- Harvest index.

B - Cowpea characters

1- Biological yield/hectare.

2- Grain yield/hectare.

3- Harvest index.

$\mathrm{C}$ - Competitive relationships and yield advantage

\section{1 - Land equivalent ratio (LER):}

It was determined according to Andrews and Kassam (1976) as follows:

$$
\begin{aligned}
& L E R=R Y \text { maize }+R Y \text { cowpea } \\
& \text { Intercropping yield of maize } \\
& R Y_{\text {Maize }}=\overline{\text { Pure stand yield of maize }} \\
& \text { Intercropping yield of cowpea } \\
& R Y_{\text {Cowpea }}= \\
& \text { Pure stand yield of cowpea }
\end{aligned}
$$

2 - Relative crowding coefficient (K):

It was determined according to De Wit (1960) as follows:

$$
\begin{aligned}
& K_{\text {Maize }}=\frac{\mathrm{ymc}}{\mathrm{ymm}-\mathrm{ym}} \times \frac{\mathrm{Zc}}{\mathrm{Zm}} \\
& R Y_{\text {Cowpea }}=\frac{\mathrm{ycm}}{\mathrm{ycc}-\mathrm{ycm}} \times \frac{\mathrm{Zm}}{\mathrm{Zc}}
\end{aligned}
$$

Where:

$\mathrm{ymm}=$ pure stand yield of maize

ycc $=$ pure stand yield of cowpea

ymc $=$ intercrop yield of maize

ycm $=$ intercrop yield of cowpea

$\mathrm{Zm}=$ sown proportion of maize in a mixture with cowpea

$\mathrm{Zc}=$ sown proportion of cowpea in a mixture with maize 


\section{3 - Aggressivity (A):}

It was determined according to Mc Gilchrist (1965) as follows:

$$
\begin{aligned}
& A_{\text {Maize }}=\frac{\mathrm{Ymc}}{\mathrm{Ymm} \times \mathrm{Zm}} \times \frac{\mathrm{Ycm}}{\mathrm{Ycc} \times \mathrm{Zc}} \\
& A_{\text {Cowpea }}=\frac{\mathrm{Ycm}}{\mathrm{Ycc} \times \mathrm{Zc}} \times \frac{\mathrm{Ymc}}{\overline{\mathrm{Ymm} \times \mathrm{Zm}}}
\end{aligned}
$$

\section{4 - Competitive ratio (CR):}

It was determined according to Willey and Rao (1980) as follows:

$$
\begin{aligned}
& C R \text { maize }=\frac{L E R \text { maize }}{L E R \text { cowpea }} \mathrm{X} \frac{Z c}{Z m} \\
& C R \text { cowpea }=\frac{L E R \text { cowpea }}{L E R \text { maize }} \mathrm{X} \frac{Z m}{Z c}
\end{aligned}
$$

The statistical analysis for data was carried out according to Gomez and Gomez (1984). L.S.D test at $5 \%$ significant level was used to compare the differences between treatment means.

\section{ESULTS AND DISCUSSION}

\section{A - Maize characters:}

\section{1 - Maize biological and grain yields:}

Results in Table (2) indicated that biological and grain yield of maize were significantly affected by plant densities and the intercropping patterns as well as their interaction in both seasons. Biological yield was gradually increased when the plant density was increased to reach the maximum value of 11.99 tons in the first season and 11.51 tons in the second season at the highest plant density (1110000 plants/hectare) with significant increase compared to the other plant densities except 83000 plant density in the first season. The results were also supported by Shivay and Sing (2000) and Al-Shebani and Alazaki (2006).
Maize grain yield/hectare was significantly increased by increasing plant density and that highest yield of 4.43 and 4.11 tons in the first and second seasons respectively, was obtained at plant density of 83000 plants/hectare with significant difference than 56000 plants/ hectare in both seasons and 67000 plants/ hectare in the second season only. In general, maize density of 83000 plants/hectare was increased grain yield compared with the other plant densities and this is true either in sole cropping or under intercropping patterns. The increase in maize grain yield that was recorded per unit area is a good indicator that the cowpea is not competitor for the maize and inter specific competition between both species is much lower than the intra specific competition. Similar results were recorded by Fisher (1977) and Shivay and Sing (2000).

Results in Table (2) also revealed that intercropping patterns significantly reduced biological and grain yield of maize compared to solid maize. The 1:1, 2:1 and 3:3 intercropping patterns when compared with solid maize produced biological yield of $68.11,91.93$ and $71.47 \%$ in the first season and $66.98,94.67$ and $74.54 \%$ in the second season respectively. The respective intercropping patterns yielded 76.92, 91.48 and $78.17 \%$ in the first season and $82.38,94.29$ and $87.14 \%$ in the second season of that grain yield of solid maize. On the other hands the biological and grain yields produced by 2:1 were significantly higher than those of $1: 1$ and $3: 3$ patterns. The reduction in biological and grain yield of maize under intercropping patterns mainly due to the reduction of area planted. These results agree with those obtained by Shivay and Sing (2000) and Hassan et al. (2008) for biological yield, and by Fisher (1997), Shivay and Sing (2000), Hassan et al. (2008) and Ahmed and Baswiad (2009) for grain yield. Interaction between plant densities and the intercropping patterns had significant effect on biological and grain yields in the two seasons.

Table 1. Mechanical and chemical analysis of the experimental soil in 2012/2013 and 2013/2014 seasons

\begin{tabular}{lcc}
\hline A - Mechanical analysis & $\mathbf{2 0 1 2 / 2 0 1 3}$ season & 2013/2014 season \\
\hline Sand (\%) & 25 & 30 \\
\hline Silt $(\%)$ & 65 & 55 \\
\hline Clay $(\%)$ & 10 & 15 \\
\hline Soil texture & Sandy loam & Sandy loam \\
\hline B - Chemical analysis & & \\
\hline E.C. $\left(\mathrm{m}\right.$ mohos $\left./ \mathrm{cm} / 25^{\circ} \mathrm{C}\right)$ & 1.3 & 1.5 \\
\hline pH $(1: 2.5$ water suspension) & 8.8 & 8.7 \\
\hline Organic matter $(\%)$ & 0.64 & 0.51 \\
\hline Total N $(\%)$ & 0.04 & 0.05 \\
\hline Available $\mathrm{P}(\mathrm{NaHCO}$ extractable) $\mathrm{ppm}$ & 12 & 14 \\
\hline
\end{tabular}




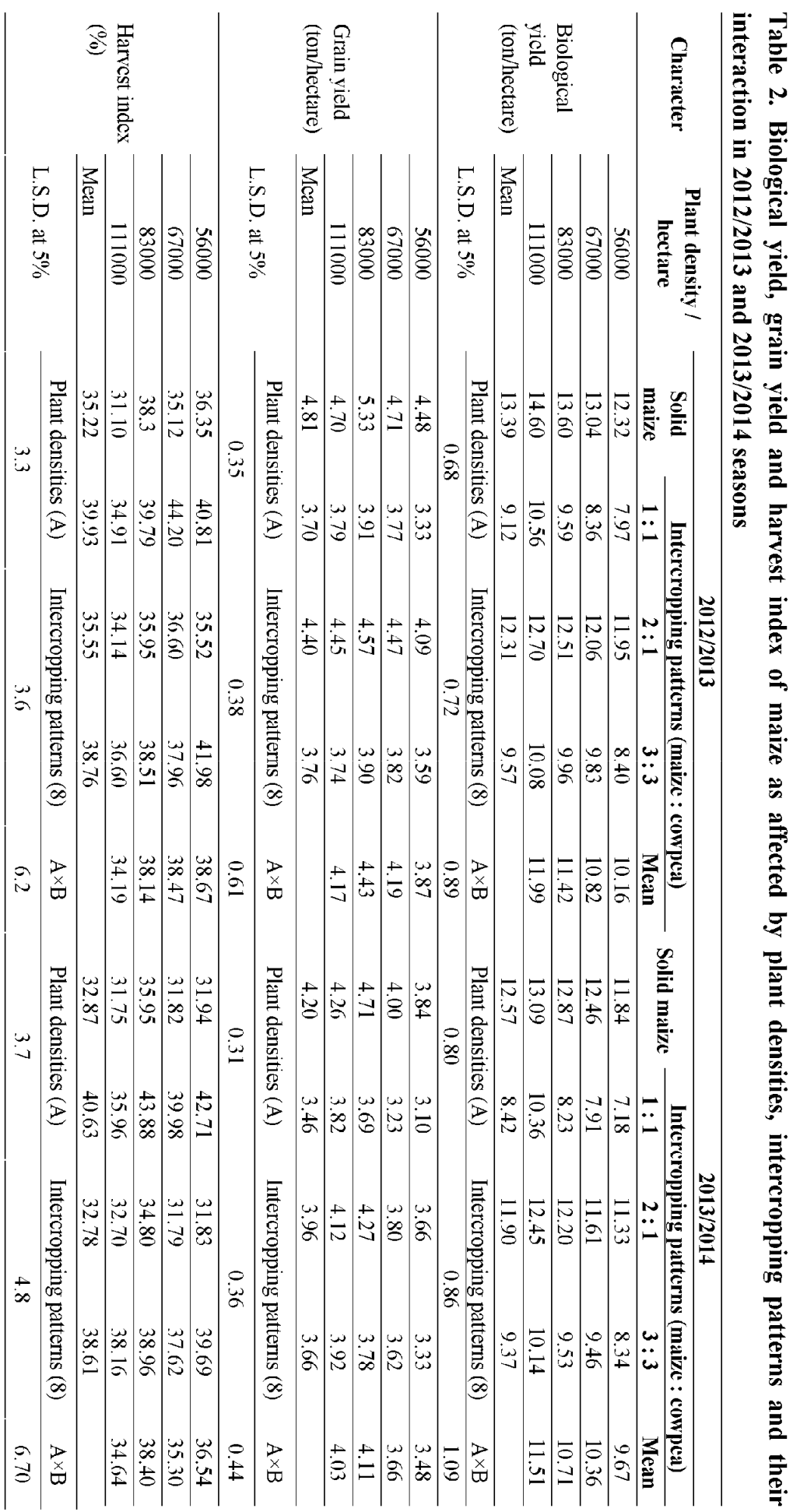


The maximum biological yield of 14.60 and 13.09 tons/ hectare were produced by sole maize at plant density of 111000 plants/hectare, followed by $2: 1$ intercropping pattern and 1110000 plants/ hectare (12.70 and 12.45 tons) and (12.51 and 12.20) at 83000 plants / hectare for the first and second seasons respectively. While the maximum grain yield of 5.33 tons in the first season and 4.71 tons in the second season was obtained by maize sole cropping at 83000 plants/ hectar . On other hand, the $2: 1$ pattern with 83000 plants/ hectare was superior to $1: 1$ and $3: 3$ patterns in biological and grain yield at all plant densities except $3: 3$ pattern at 1110000 plants/ hectare in grain yield of the second season this might be due to increased maize plant population in $2: 1$ pattern.

\section{2- Harvest index:}

It is clear from the results (Table 2) that harvest index at the highest plant density was lower than the other plant densities, while the maximum value in the first season (38.67\%) and the second season (38.40\%) was for 56000 and 83000 plants/ hectare respectively with significant difference than 111000 plant/hectare .Similar results were reported by Al-Shebani Alazaki (2006). Intercropping patterns had significant effect on maize harvest index in both seasons (Table 2). The results showed that the maximum harvest index of 39.93 and $40.63 \%$ was obtained by $1: 1$ intercropping pattern with no significant difference than $3: 3$ pattern (38.76 and $38.61 \%$ ) for the first and second seasons respectively, while the lowest harvest index was for solid maize (35.22 and $32.87 \%$ ) and for $2: 1$ intercropping pattern in the two seasons (35.55 and $32.78 \%$ ). Such results may be attributed to light use efficiency of solar radiation utilized by maize grown in $1: 1$ and 3:3 intercropping patterns which in turn enhances the conversion of light energy to chemical energy and consequently encourages the dry matter accumulation in grain. These results agree with that obtained by Alshebani and Alazaki (2006). Concerning interaction effect on harvest index of maize, the results on Table (2) indicate that interaction between plant densities and intercropping patterns significantly affected harvest index in both seasons. The maximum values of this character in the first season $(44.20 \%)$ and in the second season (43.88\%) were produced under 1:1 pattern at 67000 and 83000 plants/ hectare respectively with no significant difference compared to $3: 3$ pattern at different plant densities except 111000 plants/hectare in both seasons.

\section{B - Cowpea characters: \\ 1 - Cowpea biological and seed yields:}

Results in Table (3) showed that biological and seed yields of cowpea were significantly affected by plant densities and intercropping patterns as well as their interaction. It is evident that increasing plant density significantly increased biological and seed yields of cowpea either in sole cropping or in intercropping patterns in both seasons. The maximum values of biological yield(1.92 and 2.05 tons/ hectare) and seed yield ( 0.620 and 0.659 tons/ hectare) in the first and second seasons, respectively, were obtained at the highest plant density with significant difference in both seasons compared to 56000 and 67000 plants/ hectare. Such increase for 111000 plants/ hectare compared with 83000 plants/ hectare was significant in the second season only in biological yield, while it was not significant in both seasons for seed yield. Similar results were obtained by Shivay and Sing (2000), and Gabatshela et al. (2012).

Regarding intercropping patterns, the results (Table 3) revealed that intercropping patterns significantly reduced the biological and seed yield than sole cowpea. Biological yield under1:1, 1:2 and $3: 3$ patterns were $62.55,35.14$ and $65.64 \%$ in the first season and 60.80 , 35.60 and $68.80 \%$ in the second season, respectively, than that yield produced by sole cowpea. The respective seed yield were $60.50,33.81$ and $68.09 \%$ in the first season and 59.58, 32.90 and $69.92 \%$ in the second season when compared with that yield produced by solid cowpea. Also the results revealed that seed yield produced under 2:1 intercropping pattern was lower than that produced under $1: 1$ and $3: 3$ intercropping patterns. This reduction under intercropping patterns compared to sole cropping may largely be attributed to the reduction in plant population rather than fierce interplant competition for growth resources. The results for biological yield agreed with Shivay and Sing (2000), Hassan et al. (2008) and Gabatshela et al. (2012). The results for seed yield were supported by Marfa et al. (1979), Shivay and Sing (2000), Hassan et al. (2008), Ahmed and Baswiad (2009) and Gabatshela et al. (2012).

It is observed from the results in Table (3) that the interaction between plant densities and intercropping patterns was significant in both seasons, for both biological yield and seed yield.. The maximum biological yield of 2.90 and 3.35 tons in the first and second seasons, respectively, was obtained by sole cropping at 111000 plants/hectare without significant difference with 83000 plants/ hectare in the first season, and the maximum seed yield was obtained by sole 


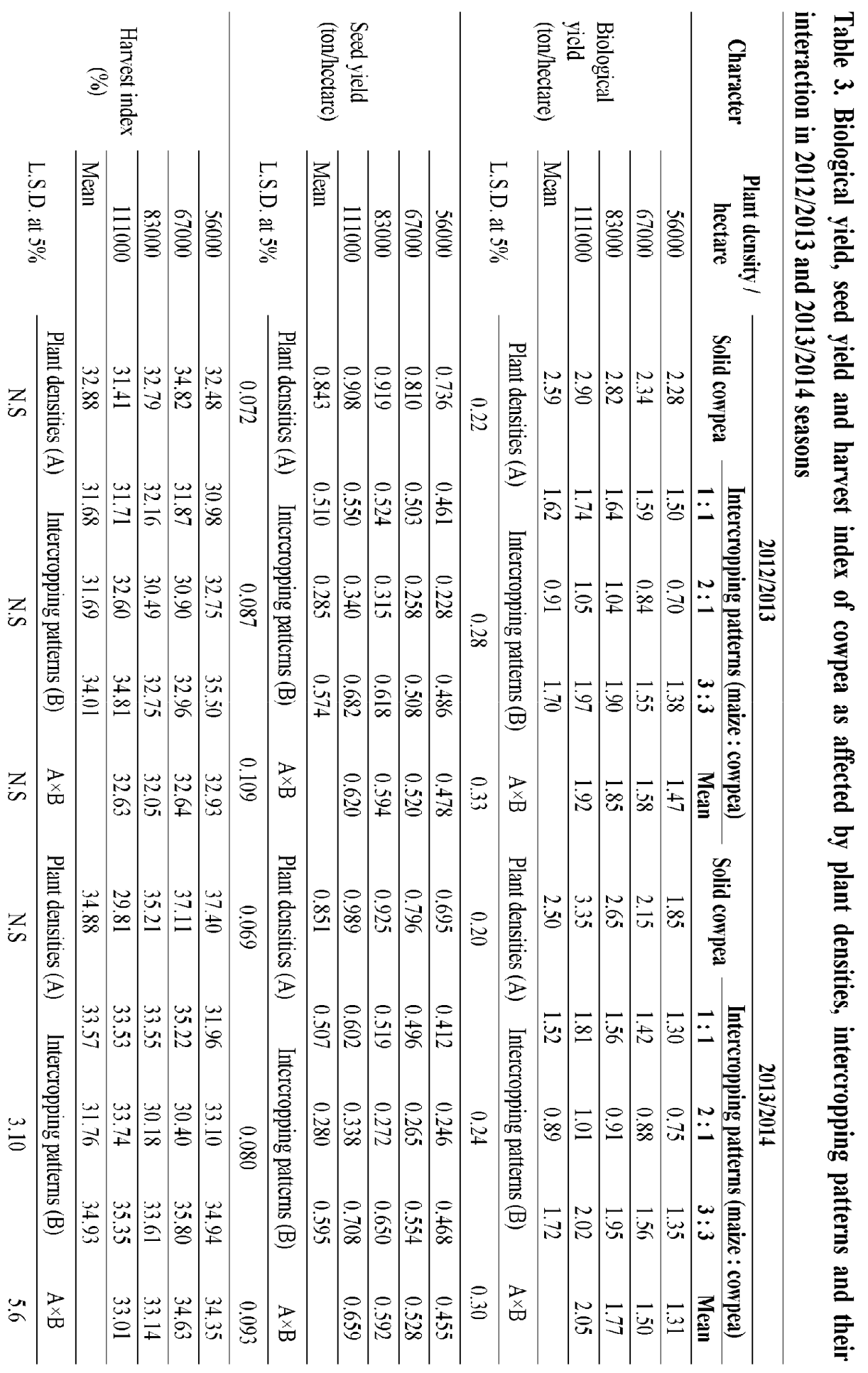


cropping at 83000 and 111000 plants/ hectare in the first season (0.919 and 908 tons/hectare) and the second season $(0.989$ and 0.925 tons/hectare), respectively. Concerning intercropping patterns, the highest bilogical yield (1.97 and 2.02 tons/hectare) and seed yield ( 0.682 and 0.708 tons) were produced under 3:3 intercropping pattern at 111000 plants/hectare in the first and second seasons, respectively, with insignificant difference with 83000 plants / hectare.

\section{2- Harvest index:}

The results in Table (3) showed that plant densities had no significant effect on harvest index in both seasons. Regarding intercropping patterns, results indicated that harvest index was significantly affected by intercropping patterns in the second season only and that maximum harvest index of $34.93 \%$ was obtained from 3:3 pattern with significant increase compared to 2:1 pattern, while this increase in the first season did not reach the level of significance. Interaction between plant densities and intercropping patterns significantly affected the harvest index in the second season only and the highest value of $37.40 \%$ was obtained at 56000 plants/ hectare under sole cropping, while the lowest value of $29.81 \%$ was for sole cropping at 111000 plants $/$ hectare.

\section{C - Competitive relationships and yield advantage:}

\section{1- Land equivalent ratio (LER):}

Results of LER are presented in Table(4) Results revealed that values of ( $R Y$ maize) were greater than those of cowpea under all combinations of intercropping patterns and plant densities except $3: 3$ intercropping pattern at 111000 plants/hectare density in the first season, and all values of relative yield of maize and cowpea were less than one, however the combined LER exceeded one at all combinations of intercropping patterns and plant densities, and that LER value of treatment of 111000 plants/ hectare density under $3: 3$ pattern was the highest (1.51 and 1.60) while the LER value of treatment of 56000 plants/ hectare density and 2:1 pattern was the lowest one (1.02 and $1.05)$ for the first and second seasons respectively. These results indicated that maize and cowpea are compatible intercrop components when they were intercropped at all combinations of intercropping patterns and plant densities with high advantage of 51 and $60 \%$ for the first and second seasons respectively when they were intercropped at the highest plant density (111000 plants/hectare) under 3:3 intercropping pattern. This means that 51 to $60 \%$ more land requires in sole cropping in order to obtain the same yield of that intercropping treatment. The results are on line with those obtained by Marfa et al. (1997), Allen and Gboura (1983), Asafu-Agyei et al. (1997), Hassan et al. (2008), Ahmed and Baswiad (2009) and Al-Shebani and Alazaki (2012).

\section{2- Relative crowding coefficient (K):}

Results in Table (5) showed that the $\mathrm{K}$ values for maize were more than one and more than those of cowpea under all combinations of intercropping patterns and plant densities except that treatment of $3: 3$ pattern and 111000 plants/ hectare density where the K value of cowpea for this treatment in the first season was more than that of maize and more than one.

\section{Table 4. Land equivalent ratio (LER) for maize and cowpea as affected by intercropping} patterns at different plant densities in 2012/2013 and 2013/2014 seasons

\begin{tabular}{|c|c|c|c|c|c|c|c|c|c|c|}
\hline \multirow{3}{*}{$\begin{array}{l}\text { Season } \\
\text { Intercropping } \\
\text { patterns } \\
\text { (maize :cowpea) }\end{array}$} & \multicolumn{5}{|c|}{$2012 / 2013$} & \multicolumn{5}{|c|}{$2013 / 2014$} \\
\hline & \multicolumn{5}{|c|}{ Plant densities (hectare) } & \multicolumn{5}{|c|}{ Plant densities (hectare) } \\
\hline & 56000 & 67000 & 83000 & 111000 & Mean & 56000 & 67000 & 83000 & 111000 & Mean \\
\hline \multicolumn{11}{|c|}{$L E R_{\text {maize }}$} \\
\hline $1: 1$ & 0.63 & 0.71 & 0.73 & 0.71 & 0.70 & 0.66 & 0.69 & 0.78 & 0.81 & 0.74 \\
\hline $2: 1$ & 0.77 & 0.84 & 0.89 & 0.84 & 0.83 & 0.78 & 0.89 & 0.81 & 0.88 & 0.84 \\
\hline $3: 3$ & 0.67 & 0.72 & 0.84 & 0.70 & 0.73 & 0.71 & 0.77 & 0.80 & 0.83 & 0.78 \\
\hline Mean & 0.69 & 0.76 & 0.82 & 0.75 & & 0.72 & 0.78 & 0.80 & 0.84 & \\
\hline \multicolumn{11}{|c|}{ LER cowpea } \\
\hline $1: 1$ & 0.45 & 0.55 & 0.57 & 0.60 & 0.54 & 0.45 & 0.54 & 0.56 & 0.65 & 0.55 \\
\hline $2: 1$ & 0.25 & 0.28 & 0.34 & 0.37 & 0.31 & 0.27 & 0.29 & 0.29 & 0.37 & 0.31 \\
\hline $3: 3$ & 0.53 & 0.55 & 0.61 & 0.81 & 0.63 & 0.51 & 0.60 & 0.70 & 0.77 & 0.65 \\
\hline Mean & 0.41 & 0.46 & 0.51 & 0.59 & & 0.41 & 0.48 & 0.52 & 0.60 & \\
\hline \multicolumn{11}{|c|}{ combined LER } \\
\hline $1: 1$ & 1.08 & 1.26 & 1.30 & 1.31 & 1.24 & 1.11 & 1.23 & 1.34 & 1.46 & 1.31 \\
\hline $2: 1$ & 1.02 & 1.12 & 1.23 & 1.21 & 1.14 & 1.05 & 1.18 & 1.10 & 1.25 & 1.15 \\
\hline $3: 3$ & 1.20 & 1.27 & 1.45 & 1.51 & 1.36 & 1.22 & 1.37 & 1.50 & 1.60 & 1.42 \\
\hline Mean & 1.10 & 1.22 & 1.33 & 1.34 & & 1.13 & 1.26 & 1.32 & 1.44 & \\
\hline
\end{tabular}


Table 5. Relative crowding coefficient(K) for maize and cowpea as affected by intercropping patterns at different plant densities in 2012/2013 and 2013/2014 seasons

\begin{tabular}{|c|c|c|c|c|c|c|c|c|c|c|}
\hline \multirow{3}{*}{\begin{tabular}{l}
\multicolumn{1}{c}{ Season } \\
Intercropping \\
patterns \\
(maize : cowpea)
\end{tabular}} & \multicolumn{5}{|c|}{$2012 / 2013$} & \multicolumn{5}{|c|}{ 2013/2014 } \\
\hline & \multicolumn{5}{|c|}{ Plant densities (hectare) } & \multicolumn{5}{|c|}{ Plant densities (hectare) } \\
\hline & 56000 & 67000 & 83000 & 111000 & Mean & 56000 & 67000 & 83000 & 111000 & Mean \\
\hline \multicolumn{11}{|c|}{$K_{\text {maize }}$} \\
\hline $1: 1$ & 1.67 & 2.42 & 2.75 & 2.46 & 2.33 & 1.93 & 2.18 & 3.62 & 4.29 & 3.01 \\
\hline $2: 1$ & 1.63 & 2.56 & 4.04 & 2.49 & 2.68 & 1.72 & 2.06 & 4.78 & 3.44 & 3.00 \\
\hline $3: 3$ & 1.74 & 2.53 & 2.73 & 2.35 & 2.34 & 2.41 & 3.32 & 4.07 & 4.96 & 3.69 \\
\hline Mean & 1.68 & 2.50 & 3.17 & 2.43 & & 2.02 & 2.52 & 4.16 & 4.23 & \\
\hline \multicolumn{11}{|c|}{$K_{\text {cowpea }}$} \\
\hline $1: 1$ & 1.01 & 1.21 & 1.33 & 1.49 & 1.26 & 0.80 & 1.16 & 1.28 & 1.86 & 1.28 \\
\hline $2: 1$ & 0.67 & 0.79 & 1.06 & 1.19 & 0.93 & 0.74 & 0.82 & 0.85 & 1.17 & 0.90 \\
\hline $3: 3$ & 1.12 & 1.24 & 2.05 & 2.88 & 1.82 & 1.02 & 1.49 & 2.36 & 3.26 & 2.03 \\
\hline Mean & 0.93 & 1.08 & 1.48 & 1.85 & & 0.85 & 1.16 & 1.50 & 2.10 & \\
\hline \multicolumn{11}{|c|}{$K=K_{\text {maize }} K_{\text {cowpea }}$} \\
\hline $1: 1$ & 1.68 & 2.93 & 3.66 & 3.67 & 2.99 & 1.55 & 2.52 & 4.62 & 8.00 & 4.17 \\
\hline $2: 1$ & 1.09 & 2.03 & 4.29 & 2.97 & 2.60 & 1.28 & 1.68 & 4.05 & 4.02 & 2.76 \\
\hline $3: 3$ & 1.95 & 3.13 & 5.60 & 6.77 & 4.36 & 2.47 & 4.96 & 9.61 & 16.19 & 8.31 \\
\hline Mean & 1.57 & 2.70 & 4.52 & 4.47 & 3.32 & 1.77 & 3.05 & 6.09 & 9.40 & \\
\hline
\end{tabular}

Table 6. Aggressivity (A) for maize and cowpea as affected by intercropping patterns at different plant densities in 2012/2013 and 2013/2014 seasons

\begin{tabular}{|c|c|c|c|c|c|c|c|c|c|c|}
\hline \multirow{3}{*}{$\begin{array}{l}\text { Season } \\
\text { Intercropping } \\
\text { patterns } \\
\text { (maize :cowpea) }\end{array}$} & \multicolumn{5}{|c|}{$2012 / 2013$} & \multicolumn{5}{|c|}{$2013 / 2014$} \\
\hline & \multicolumn{5}{|c|}{ Plant densities (hectare) } & \multicolumn{5}{|c|}{ Plant densities (hectare) } \\
\hline & 56000 & 67000 & 83000 & 111000 & Mean & 56000 & 67000 & 83000 & 111000 & Mean \\
\hline \multicolumn{11}{|c|}{$A_{\text {maize }}$} \\
\hline $1: 1$ & +0.25 & +0.32 & +0.29 & +0.23 & +0.27 & +0.33 & +0.31 & +0.45 & +0.32 & +0.35 \\
\hline $2: 1$ & +0.39 & +0.40 & +0.30 & +0.24 & +0.33 & +0.35 & +0.33 & +0.46 & +0.30 & +0.36 \\
\hline $3: 3$ & +0.29 & +0.33 & +0.12 & -0.08 & +0.21 & +0.40 & +0.34 & +0.20 & +0.14 & +0.27 \\
\hline Mean & +0.31 & +0.35 & +0.24 & +0.18 & & +0.36 & +0.33 & +0.37 & +0.25 & \\
\hline \multicolumn{11}{|c|}{ A cowpea } \\
\hline $1: 1$ & -0.25 & -0.32 & -0.29 & -0.23 & -0.27 & -0.33 & -0.31 & -045 & -0.32 & -0.35 \\
\hline $2: 1$ & -0.39 & -0.40 & -0.30 & -0.24 & -0.33 & -0.35 & -0.33 & -046 & -0.30 & -0.36 \\
\hline $3: 3$ & -0.29 & -0.33 & -0.12 & +0.08 & -0.21 & -0.40 & -0.34 & -020 & -0.14 & -0.27 \\
\hline Mean & -0.31 & -0.35 & -0.24 & -0.18 & & -0.36 & $\begin{array}{l}-0.33 \\
\end{array}$ & -0.37 & -0.25 & \\
\hline
\end{tabular}

The values of $\mathrm{K}$ revealed that all combinations of plant densities and intercropping patterns achieved yield advantage compared to sole planting of both crops where $\mathrm{K}$ values were more than one and the greatest values of 6.77 in the first season and 16.19 in the second season were obtained from 3:3 pattern at 111000 plants/hectare. These results indicated the superiority of the intercropping of cowpea with maize at all combinations of intercropping patterns and plant densities over the pure stand in terms of the use of environment resources during plant growth and development. The results closely agree with the results obtained by Hassan et al. (2008) and Al-Shebani and Alazaki (2012).

\section{3- Aggressivity (A):}

Results on aggressivity (Table 6) showed that average values of 2:1 pattern was higher than those of $1: 1$ and $3: 3$ patterns while the least value was for $3: 3$ pattern. Regarding the interaction between intercropping pattern and plant densities, the results showed that the least value of (0.08) in the first season and of (0.14) in the second season was for $3: 3$ intercropping combined with plant density of 111000 plants/hectare whereas the highest value of (A) was obtained from 2:1 pattern combined with plant density of 67000 plants/hectar in the first season (0.40) and $83000 \mathrm{plant} / \mathrm{hectare}$ in the second season $(0.46)$. 
Table 7. Competitive ratio (CR) for maize and cowpea as affected by intercropping patterns at different plant densities in 2012/2013 and 2013/2014 seasons

\begin{tabular}{|c|c|c|c|c|c|c|c|c|c|c|}
\hline \multirow{3}{*}{\begin{tabular}{l}
\multicolumn{1}{c}{ Season } \\
Intercropping \\
patterns \\
(maize : cowpea)
\end{tabular}} & \multicolumn{5}{|c|}{ 2012/2013 } & \multicolumn{5}{|c|}{ 2013/2014 } \\
\hline & \multicolumn{5}{|c|}{ Plant densities (hectare) } & \multicolumn{5}{|c|}{ Plant densities (hectare) } \\
\hline & 56000 & 67000 & 83000 & 111000 & Mean & 56000 & 67000 & 83000 & 111000 & Mean \\
\hline \multicolumn{11}{|c|}{$C R_{\text {maize }}$} \\
\hline $1: 1$ & 1.40 & 1.29 & 1.28 & 1.18 & 1.29 & 1.47 & 1.28 & 1.39 & 1.25 & 1.35 \\
\hline $2: 1$ & 1.53 & 1.48 & 1.28 & 1.11 & 1.35 & 1.42 & 1.38 & 1.55 & 1.17 & 1.38 \\
\hline $3: 3$ & 1.26 & 1.31 & 1.09 & 0.95 & 1.15 & 1.39 & 1.28 & 1.14 & 1.08 & 1.22 \\
\hline Mean & 1.40 & 1.36 & 1.22 & 1.08 & & 1.43 & 1.31 & 1.36 & 1.17 & \\
\hline \multicolumn{11}{|c|}{$C R_{\text {cowpea }}$} \\
\hline $1: 1$ & 0.71 & 0.78 & 0.78 & 0.85 & 0.78 & 0.68 & 0.78 & 0.72 & 0.80 & 0.75 \\
\hline $2: 1$ & 0.62 & 0.68 & 0.81 & 0.92 & 0.76 & 0.70 & 0.73 & 0.77 & 0.85 & 0.76 \\
\hline $3: 3$ & 0.79 & 0.76 & 0.92 & 1.06 & 0.88 & 0.72 & 0.78 & 0.88 & 0.93 & 0.83 \\
\hline Mean & 0.71 & 0.74 & 0.84 & 0.94 & & 0.70 & 0.76 & 0.79 & 0.86 & \\
\hline
\end{tabular}

Also it was observed from the results that maize had positive values of (A) while cowpea had negative values at all combinations of intercropping patterns and plant densities except that treatment of $3: 3$ patterns combined with 111000 plants/ hectare density in the first season where the value of (A) for cowpea in this treatment was positive $(+0.08)$ while it was negative for maize $\quad(-0.08)$. It is evident that cowpea requires $50 \%$ from the intercropping area under $3: 3$ pattern to contribute positively and avoid the sever competition of maize plants. Similar results were obtained by Hassan et al. (2008) and El-Shebani and Alazaki (2012).

\section{4- Competitive ratio (CR):}

To estimate the exact degree of competition, competitive ratio (CR) was calculated. The results on Table (7) indicated that maize was always more competitive than cowpea. The results, also indicated that competitive ratio of maize was higher under $2: 1$ pattern, while competitive ratio of cowpea was higher under 3:3 patterns, the same trend was observed at all combinations of plant density and intercropping patterns. Also, the results showed the $(\mathrm{CR})$ of maize was reduced while cowpea (CR) increased by increasing plant density and this true under different intercropping patterns in the two seasons. In all cases, (CR) values of maize exceeded the unity, whereas, (CR) values of cowpea were below the unity. This tendency could be interpreted due to higher growth rate of maize than cowpea during their life cycle together since maize is a $\mathrm{C}_{4}$ crop. The results are in agreement with those obtained by Hassan et al. (2008) and Al-Shebani and Alalzaki (2012).

\section{REFERENCES}

Ahmed, M. A. and A. S. Baswiad. 2009. Inter and intra competition and land equivalent ratio under different intercropping systems of maize and cowpea. Yemeni J. Agric. Res, Nasser's Fac. Agric. Sci., No. 28: 11-17.(in Arabic).

Allen, J. R. and R. K. Gboura. 1983. Yield of corn, cowpea and sorghum under different intercropping systems. Agron. J., (75): 1005-1009.

Al-Shebani, Y. A. A. and A. M. A. Alazaki. 2006. Effect of intercropping patterns and plant dernsities on yield and yield components of maize and bean. J. Agric. Mansoura Univ., 34 (4): 231-247.

Al-Shebani, Y. A. A. and A. M. A. Alazaki. 2012. Land equivalent ratio and several competitive relationships of intercropping maize and beans under irrigated conditions. Egypt J. Appl. Sci., 27 (2): 67-86.

Andrews, D. J. and A. H. Kassam. 1976. The importance of multiple cropping in increasing world food supplies. Multiple cropping. A. S. A. Special Publication, No. 27: $1-10$.

Asafu-Agyei, J. N., K. Ahenkora, B. Banful and K. S. Ennin. 1997. Sustaining food production in Ghana. In the produce of cereal legumes based cropping systems. Semi-Arid Res. Agency Sci., Tech and Res. Commission of OAU., 409416.

De wit, C. T. 1960. On competition . Verslag Landbouwkundige Onderzoeck No. 66:1-82, (C.A. Willey, RW. 1979a). Intercropping its important and research need. Part 1.( C.Fr. Field Crop Abst., (32): 1-10).

Fisher, N. M. 1977. Studies in mixed cropping. 2 - Population pressures in maize- cow pea mixtures. Exp. Agric. 13-191. (C.F. Field Crop Abst. 3 (2): 1046 - 1478).

Gabatshela, M., T. K. Legwaila and W. M. Marokana. 2012. Effects of intercropping on the performance of maize and cowpea in Botswana. Inter. J. Agric. And Fore., 2 (6): 307-310. 
Gomez, K. A. and A. A. Gomez. 1984. Statistical Procedures for Agricultural Research. John Wiely and Sons. Inc., New York.

Hassan, M. A., M. O. Ganzal and A. K. Basbaa. 2008. A study on intercropping maize and cowpea under different nitrogen rates. Yemeni J. of Agric. Res. Nasser's Fac. Agric. Sci., No. 27: 1-17.

Marfa, R. C., M. A. Lira, A. S. S. Areoveredm, G. Roberio and M. A. Faris. 1979. Studies on the intercropping of sorghum and corn with Phaseolus bean and cowpea. Proc. of International Workshop on Intercropping. Hyderabad, India: a (10-13 January) 47-51.
Mc Gilchrist, A. 1965. Analysis of competition experiments. Biometric, 21(975-985).

Remison, S.U. 1978. Neighbor effects between maize and cowpea at various levels of nitrogen and phosphorus. Exp. Agric., 14:(205-212).

Shivay, X.S. and R. R. Singh. 2000. Growth, yield attributes, yield and nitrogen uptake of maize as influenced by cropping system and nitrogen. Annuals of Agric. Res. 2(4): 497-498.

Willey, R.W. and M.R. Rao. 1980. A competitive ratio for quantifying competition between intercrops. EXP. Agric., (16): 117-125.

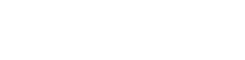 \\ تأثير الكثلة النبلتية وظلم التحمل علل المحصط والملافلت التنالفية للذرة الثامية واللوبيا}

محمد علي Rسن، ملجدسعيسالم بلمعافى وكلملة عبد الرشيد إبراهيم

- أدت زياة الكثافة إلى زياةة معنوي ـة ف مي المح صصول

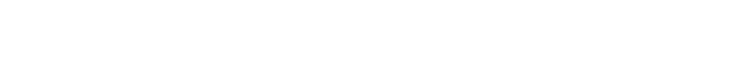

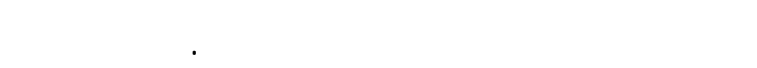
التحمل إلى قص معنوي في المح صول البيول -وجي فوني

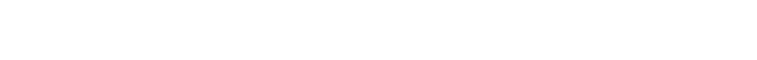

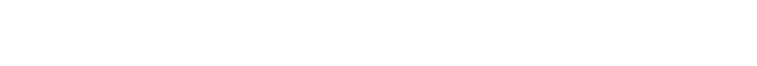
على المحصول البيول ـوجي ومح صصل الب ذذور ف مي الموسمين ودليل الحصاد في الموسم الثالي حي ثاث ت م

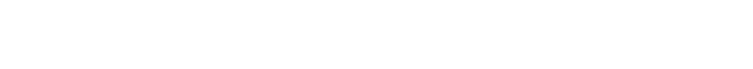

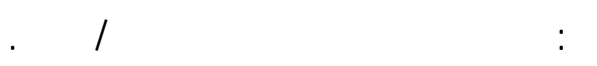
- أوضح تقدير معلمل إستغلل الأرض( LER) ومعلم لـ

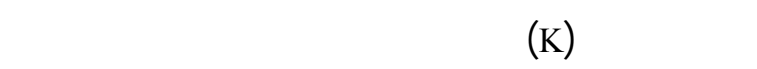

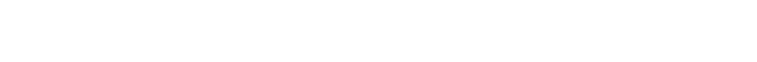

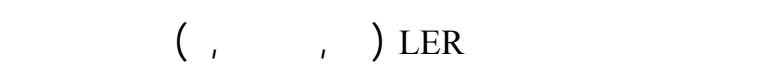

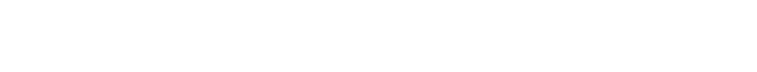

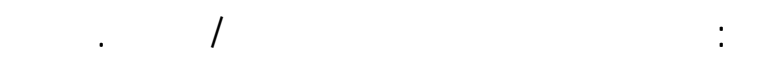
لظٔهرت قيم العدوانية ونسبة التنافس أن الذرة الـ شلمية المحصول للسائد واللوبيا المحصول المسود.
فذت تجربتلن حقليتلن في المزرعة البحثي لمة لمط ـة

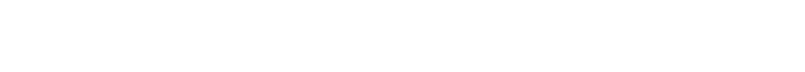

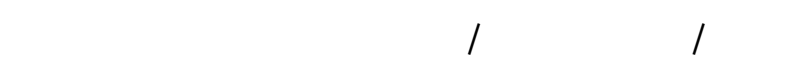

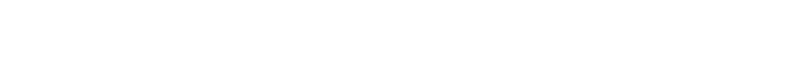

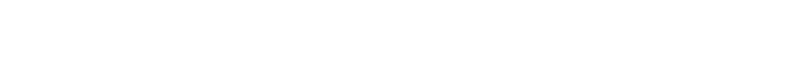
لستخدم في هذه الدرلسة أرعع كثلف لت نباتي ـة ( . .07،

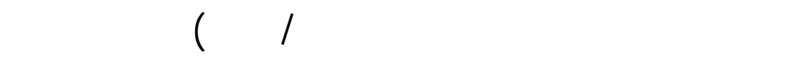

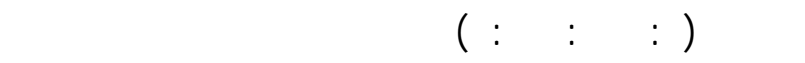
التوالمي بالإضافة إلى الزراعة المفرثة. وفيمايلي أهم النتائج المتحصل عليها:

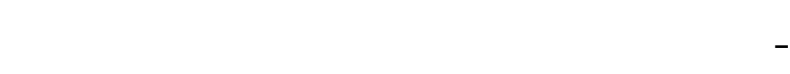

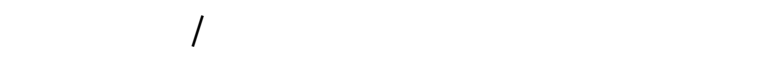

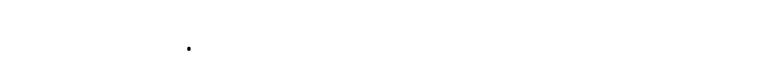
التحمل إل قصص معنوي ف ي المح صول البيول ـوجي

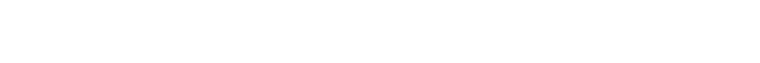

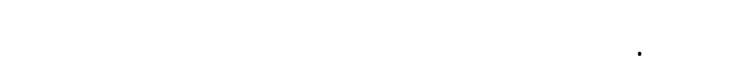
البيولوجي ومحصول الحبوب ودليل الحصاد وق ـد ت م م الحصول على أعلى محصول حبوب من ظلم التحمي لل

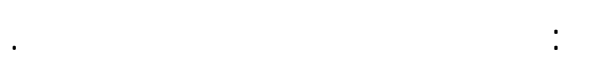

